Cornell University Law School Scholarship@Cornell Law: A Digital Repository

Spring 2007

\title{
The Detention and Trial of Enemy Combatants: A Drama in Three Branches
}

Michael C. Dorf

Cornell Law School, michaeldorf@cornell.edu

Follow this and additional works at: http://scholarship.law.cornell.edu/facpub

Part of the Constitutional Law Commons, International Law Commons, and the Jurisdiction Commons

\section{Recommended Citation}

Dorf, Michael C., "The Detention and Trial of Enemy Combatants: A Drama in Three Branches" (2007). Cornell Law Faculty Publications. Paper 115.

http://scholarship.law.cornell.edu/facpub/115

This Article is brought to you for free and open access by the Faculty Scholarship at Scholarship@Cornell Law: A Digital Repository. It has been accepted for inclusion in Cornell Law Faculty Publications by an authorized administrator of Scholarship@Cornell Law: A Digital Repository. For more information, please contact jmp8@cornell.edu. 


\section{The Detention and Trial of Enemy \\ Combatants: A Drama in Three Branches}

MICHAEL C. DORF

Within a week of the attacks of 11 September 2001, the United States Congress authorized the President to "use all necessary and appropriate force against those nations, organizations, or persons he determines planned, authorized, committed, or aided the terrorist attacks ...." Although this Authorization for Use of Military Force (AUMF) was not literally a declaration of war, President George W. Bush interpreted it as activating his full wartime powers as Commander in Chief, including the power to detain enemy combatants. Then, claiming that Taliban, al Qaeda, and other irregular fighters in Afghanistan and elsewhere were entitled neither to the procedural protections of the criminal justice system, nor to the humanitarian protections of the Geneva Conventions, the Bush administration asserted an entitlement to hold detainees indefinitely, subject them to harsh methods of interrogation, and try them, if it chose not to simply hold them, before specially constituted military commissions. Moreover, the administration eventually claimed, the civilian courts were powerless to rule on the legality of such measures.

Inevitably, and almost immediately, these policies were challenged in the federal courts. However, the cases did not make their way to the point of a Supreme Court decision until June of 2004, and during the intervening period, Congress was almost entirely silent. Indeed, Congress would not legislate on the subject of detainee treatment until it enacted the Detainee Treatment Act (DTA) at the end of $2005,{ }^{2}$ and even then, it spoke with less than complete

\footnotetext{
${ }^{1}$ Authorization for Use of Military Force, U.S. Public Law 107-40, 115 Stat. 224 107th Cong., 1st sess. (18 September 2001), note following 50 U.S.C.A. $\$ 1541$ (2000 ed., Supp. III).

${ }^{2}$ Detainee Treatment Act of 2005, U.S. Public Law 109-148, div. A, tit. X, 119 Stat. 2739 109th Cong., 1 st sess. ( 30 December 2005 ) (to be codified at 42 U.S.C. $\$ \$ 2000 \mathrm{dd}$ to $2000 \mathrm{dd}-1$ and other provisions of the U.S. Code).
}

MICHAEL C. DORF is the Isidor \& Seville Sulzbacher Professor of Law at Columbia University and an expert in U.S. constitutional law and federal court jurisdiction. His most recent book is No Litmus Test: Law Versus Politics in the Twenty-First Century. 
clarity. Accordingly, in assessing the legality of the administration's treatment of detainees, the Supreme Court has had to address the delicate question of constitutional limits on the political branches' respective war powers, while attempting to squeeze meaning from highly ambiguous statutory text. Thus far, the Court's approach has been to avoid sweeping decisions about the scope of individual rights. Instead, in each of its three leading rulings-Hamdiv. Rumsfeld, ${ }^{3}$ Rasul v. Bush, ${ }^{4}$ and Hamdan v. Rumsfeld ${ }^{5}$-the Court has rejected the proposition that the initial 2001 AUMF conferred on the President the sweeping powers he has claimed.

The Court's decisions have thus been "democracy-forcing," in the sense that they have required the President to seek authorization for his approach from Congress, and in the fall of 2006, Congress largely obliged. Its enactment of the Military Commissions Act (MCA) ${ }^{6}$ authorized indefinite detention based on findings of a military panel, trial by special military commission, and only limited access to domestic courts to challenge these determinations. Notably, although the DTA and MCA maintain criminal penalties for U.S. military and civilian personnel who commit future acts of torture or other "grave breaches" of the Geneva Conventions' Common Article 3, they provide immunity for some past such acts, and they prevent detained aliens from objecting to such practices in a civilian court. This article explains how the interactions among a largely passive Congress, an extraordinarily assertive President, and a divided but determined Supreme Court led to the MCA.

\section{Unlawful Enemy Combatants}

The lynchpin of the Bush administration's claimed authority over detainees is the category of "unlawful enemy combatants." Persons engaging in ordinary crime within the United States are entitled to be tried in civilian courts, thereby triggering the well-known protections of the Bill of Rights: right to counsel, right to present evidence, right to confront adverse witnesses, and so forth. Persons engaging in warfare, however, need not be treated as criminal defendants. In a conventional war, captured enemy soldiers must be treated humanely and cannot be tried for their acts on the battlefield, unless those acts violated the law of war. The law of war, in turn, originally derived its authority from the customary practices of nations, but in the twentieth century became codified in a series of treaties to which the United States is a signatory: the Geneva Conventions.

There is, in addition, an intermediate category between common criminals and prisoners of war: persons who engage in warfare but because of

${ }^{3}$ Hamdi v. Rumsfeld, 542 U.S. 507 (2004).

${ }^{4}$ Rasul v. Bush, 542 U.S. 466 (2004).

${ }^{5}$ Hamdan v. Rumsfeld, 126 S. Ct. 2749 (2006).

${ }^{6}$ Military Commissions Act of 2006, U.S. Public Law 109-366, 120 Stat. 2600 109th Cong., 2nd sess. (17 October 2006). 
the methods and organization of their forces, sacrifice the protections of the Geneva Conventions. "Unlawful enemy combatants" sacrifice much of the protection afforded by the international law of war-just how much has been one of the most hotly contested questions-either because they target civilians or blend into the civilian population so as to render the enemy unable to distinguish between civilians and combatants. The 1977 Additional Protocols protect even such guerilla fighters, ${ }^{7}$ but the United States never ratified these provisions. Accordingly, the Bush administration has consistently argued that Taliban, al Qaeda, and other irregular fighters can be detained, questioned, and tried without regard to the niceties of the Geneva Conventions.

\section{Detention versus Trial and Aliens versus Citizens}

The leading cases have thus far addressed two principal questions. First, what limits, if any, apply to the president's power to detain persons deemed unlawful enemy combatants? And second, if the administration opts to try a detainee for war crimes, what kind of tribunal must it use? No Supreme Court case has yet challenged the conditions of confinement at the U.S. naval base at Guantanamo Bay or elsewhere, although the Court's rulings in the detention and trial cases have implications for conditions of confinement.

Although the vast majority of detainees held by the government are aliens, a few citizens have also been captured, detained, and charged. John Walker Lindh, an American convert to Islam, was captured in Afghanistan and, for reasons that were never made clear by the administration, charged in a civilian court, in which he pleaded guilty to fighting for the Taliban and carrying a weapon. He was sentenced to twenty years' imprisonment. ${ }^{8}$ Another American convert to Islam, Jose Padilla, by contrast, was held in military custody. A federal appeals court ruled that form of detention unlawful, ${ }^{9}$ but the Supreme Court vacated the ruling because it found that Padilla had filed his habeas corpus petition in the wrong federal court. ${ }^{10}$ After further proceedings, the government announced, again without explanation, that it would charge Padilla in civilian court after all. ${ }^{11}$ Meanwhile, the government chose to prosecute one alien detainee-Zacarais Moussaoui-in civilian court, yet again without

\footnotetext{
${ }^{7}$ Protocol Additional to the Geneva Conventions of 12 August 1949, and Relating to the Protection of Victims of International Armed Conflicts (Protocol I), 8 June 1977, 1125 U.N.T.S. 3; Protocol Additional to the Geneva Conventions of 12 August 1949, and Relating to the Protection of Victims of Non-International Armed Conflicts (Protocol II), 8 June 1977, 1125 U.N.T.S. 609.

${ }^{8}$ See Katherine Q. Seelye, "Threats and Responses: The American in the Taliban; Regretful Lindh Gets 20 Years in Taliban Case," The New York Times, 5 October 2002.

${ }^{9}$ Padilla v. Rumsfeld, 352 F.3d 695 (2d Cir. 2003).

${ }^{10}$ Rumsfeld v. Padilla, 542 U.S. 426 (2004).

${ }^{11}$ See Padilla v. Hanft, 126 S. Ct. 1649, 1650 (2006) (Kennedy, J., concurring in the denial of certiorari).
} 
explanation for the choice of forum. Moussaoui pled guilty to conspiring with al Qaeda operatives, ${ }^{12}$ and was sentenced to life imprisonment. ${ }^{13}$

\section{The Hamdi Case}

The Supreme Court has thus far addressed the merits of exactly one case in which the government sought to hold a U.S. citizen in military custody without civilian judicial oversight. That case concerned Yaser Esam Hamdi, who was born in Louisiana. Under Section I of the Fourteenth Amendment, he is therefore a citizen of the United States, even though he spent most of his life outside this country. After being captured during the Afghanistan conflict, Hamdi was initially held at the naval base in Guantanamo Bay, Cuba. But when his American citizenship came to light, the government transported him from there to the brig at the Norfolk naval station. Habeas corpus petitions were filed on his behalf, and after a number of contentious proceedings in the lower federal courts, Hamdi's case reached the Supreme Court. Throughout the course of litigation, the government took the position that a wartime determination by the President or his deputies that an individual was an unlawful enemy combatant should be conclusive on the courts.

According to the government, Hamdi's citizenship was no bar to military custody. The government placed principal reliance on the so-called Nazi Saboteur Case, Ex Parte Quirin. ${ }^{14}$ There, the Supreme Court rejected statutory and constitutional challenges to the trial by military commission of German agents who, during World War II, landed submarines in the United States, discarded their uniforms, and proceeded to attempt to destroy civilian infrastructure. The Court found that neither the international law of war nor the Articles of War that Congress had adopted extended procedural protections of the sort sought by the petitioners to "unlawful enemy belligerents." Crucially, one of the petitioners, Herbert Hans Haupt, was a U.S. citizen; yet the Court did not find this fact significant.

Understandably, much of the technical legal argument in Hamdi centered around how to read the Quirin decision. A pair of odd bedfellows, Justice Antonin Scalia, arguably the Court's most conservative member, and Justice John Paul Stevens, arguably its most liberal member, would have utterly rejected the government's position. In their view, the Supreme Court's decision in Quirin "was not [its] finest hour."15 Further, even if respected, Quirin itself suggested a crucial distinction: there, the petitioners conceded that they were

${ }^{12}$ See Neil A. Lewis, "Moussaoui Tells Court He's Guilty of a Terror Plot," The New York Times, 23 April 2005.

${ }^{13}$ See Neil A. Lewis, "Moussaoui Given Life Term by Jury Over Link to 9/11," The New York Times, 4 May 2006.

${ }^{14}$ Ex Parte Quirin, 317 U.S. 1 (1942).

${ }^{15}$ Hamdi v. Rumsfeld, 542 U.S. 507, 569 (2004) (Scalia, J., joined by Stevens, J., dissenting). 
part of the German force; Hamdi, by contrast, claimed that he had been mistakenly swept up in Afghanistan. As a U.S. citizen, Justices Scalia and Stevens would have ruled, Hamdi was entitled to be tried, if at all, for treason by a civilian court with its full procedural protections.

At the other extreme, Justice Clarence Thomas would have accepted the government's argument. Allowing for the possibility that Congress might have the power to limit the president's ability to employ military commissions, Justice Thomas nonetheless noted that Congress had taken no such limiting action. On the contrary, he read the AUMF as adding congressionally sanctioned authority to the president's already considerable powers as Commander in Chief. The power to detain unlawful enemy combatants, Justice Thomas concluded, "includes making virtually conclusive factual findings." 16

The lead opinion in the Hamdi case was written by Justice Sandra Day O'Connor, and it staked out a middle course between the two aforementioned positions. ${ }^{17}$ Justice O'Connor conceded two crucial points to the administration. First, on the strength of Quirin, she acknowledged that the Constitution poses no bar to military detention of a U.S. citizen, even if he contests the grounds for his detention. Second, she read the general language of the September 2001 AUMF to include the usual incidents of war, including detention of persons deemed enemy combatants.

Despite these substantial concessions to the Bush administration, the most quotable line from the lead opinion in Hamdi was a rebuke: "A state of war is not a blank check for the President when it comes to the rights of the Nation's citizens." ${ }^{18}$ In substance, this meant that while the government could hold U.S. citizens in military custody, the Court would scrutinize the procedures used to determine whether someone is in fact an unlawful combatant. The president's say-so is not sufficient.

Just what procedures were required? The Hamdi lead opinion invoked a 1976 precedent that set forth a general test for due process that balances the individual interest against that of the government. ${ }^{19}$ Weighing these factors, the plurality found that at a minimum, a person the government seeks to designate as an unlawful enemy combatant must "receive notice of the factual basis for his classification, and a fair opportunity to rebut the Government's factual assertions before a neutral decisionmaker." ${ }^{20} \mathrm{He}$ would also be entitled to assistance of counsel. At the same time, the Court gave considerable leeway to

\footnotetext{
${ }^{16}$ Hamdi, 542 U.S. at 589 (Thomas, J., dissenting).

${ }^{17}$ Justice O'Connor spoke for a plurality of herself, Chief Justice Rehnquist, Justice Kennedy, and Justice Breyer. Yet a fourth view was taken by Justices Souter and Ginsburg, who would have ruled that the AUMF did not authorize Hamdi's detention, which was therefore unlawful under another federal statute, the Non-Detention Act, 18 U.S.C. $\$ 4001(\mathrm{a})$. The latter prohibits imprisonment or detention of a citizen "except pursuant to an Act of Congress."

${ }^{18}$ Hamdi, 542 U.S. at 536.

${ }^{19}$ See Mathews v. Eldridge, 424 U.S. 319, 335 (1976).

${ }^{20}$ Hamdi, 542 U.S. at 533.
} 
the government to depart from procedures associated with civilian courts in criminal cases. The government could place the burden of disproving its evidence on the defendant, could introduce hearsay, and could utilize military as opposed to civilian tribunals to make the combatant status determination.

Thus, while Hamdi sent a powerful rhetorical message about the limits of presidential power even in wartime, it was hardly an unqualified triumph for civil liberties.

\section{The Rasul Case}

The same day that it decided Hamdi, the Supreme Court decided another case, Rasul v. Bush, that was of far greater practical significance. For while the Hamdi case addressed the standards applicable to the classification and detention of Hamdi and a tiny handful of other U.S. citizens held by the government, Rasul concerned the detention of aliens, who comprised the overwhelming majority of detainees.

The issue in Rasul was whether aliens held at the U.S. naval base in Guantanamo Bay, Cuba, could file habeas corpus petitions in federal court. The government took the position that they could not. Even if their detention violated federal statutes, the U.S. Constitution, and international law, according to the government, the federal courts had no jurisdiction to entertain the alien detainees' challenges.

Just as the government had relied in Hamdi on the World War II case of $E x$ Parte Quirin, so in Rasul the government invoked another World War II precedent, Johnson v. Eisentrager. ${ }^{21}$ The United States had tried German nationals captured in China for the crime of continuing to engage in warfare after their government had surrendered. The Germans challenged the lawfulness of the military commissions that tried and convicted them, but the Court rejected their claims on jurisdictional grounds.

The Eisentrager Court found that the habeas corpus statute did not authorize suit, and that this result was fully consistent with the Constitution. The Constitution confers on nonresident aliens no right of access to U.S. courts, the Court reasoned.

Nonetheless, in Rasul, a divided Supreme Court ruled that there was jurisdiction over habeas corpus petitions filed by Guantanamo Bay detainees. The justices suggested that some of the factors that had led the Eisentrager Court to find no constitutional entitlement to habeas were absent in Rasul. Ultimately, however, the Court found no need to resolve the constitutional question. The majority concluded that because the naval base was, for all practical purposes, U.S. territory, the habeas corpus statute applied to persons held there. The statutory aspect of Eisentrager, the Rasul Court said, had been superseded by subsequent decisions.

\footnotetext{
${ }^{21}$ Johnson v. Eisentrager, 339 U.S. 763 (1950).
} 
Accordingly, the Rasul majority paved the way for the lower courts to entertain habeas petitions from all Guantanamo Bay detainees. The Supreme Court said nothing, however, about the substantive merits of the claims pressed by the detainees.

\section{The Hamdan Case, the Detainee Treatment Act, and the Military Commissions ACT}

There matters stood until the Supreme Court granted review in Hamdan. After the Court accepted the case for review, but before the case was argued, Congress enacted the DTA. Among other things, it stripped the federal courts of the authority to hear habeas corpus petitions by detainees facing the possibility of trial by military commission, although it did provide for statutory and constitutional (but not international-law-based) challenges to be brought after conviction by such a commission. Yet it was not entirely clear whether the DTA's jurisdiction-stripping provisions even applied to pending cases such as Salim Ahmed Hamdan's, rather than applying only to future cases. Nor was it clear whether the application of the DTA to pending cases would satisfy the Constitution, absent a valid suspension of the privilege of the writ of habeas corpus.

Although once again avoiding a constitutional ruling on the permissible limits that can be placed on habeas corpus, the Supreme Court's decision in Hamdan was, in nearly all of its particulars, a major setback for the Bush administration's executive unilateralism.

As for the facts, Hamdan himself appeared to be closer to the events of 11 September 2001 than either Hamdi or Shafiq Rasul. Hamdan was delivered to U.S. military forces in Afghanistan in late 2001, detained at the U.S. naval base at Guantanamo Bay, Cuba, and eventually charged with conspiracy to attack civilians in his alleged capacity as driver and bodyguard for Osama bin Laden. Hamdan argued that trial by military commission was illegal, but lost in the court of appeals, where John Roberts, then a circuit judge, joined a decision finding, among other things, that Hamdan's claims were premature. ${ }^{22}$ Because of his earlier participation, now-Chief Justice Roberts took no part in the case at the Supreme Court.

Justice Stevens wrote the lead opinion in Hamdan, which Justices David Souter, Ruth Bader Ginsburg, and Stephen Breyer joined in full, and which Justice Anthony Kennedy-true to form as the crucial swing vote on the postO'Connor Court-joined in part. Justices Scalia, Thomas, and Samuel Alito dissented from nearly every important aspect of the Court's ruling. Justice Stevens garnered a full, five-justice majority for the following propositions:

- The DTA did not apply to pending cases and thus did not strip the Supreme Court of jurisdiction to hear Hamdan's case, nor would it deprive lower courts of jurisdiction over petitions filed before the DTA was enacted in late 2005.

\footnotetext{
${ }^{22}$ See Hamdan v. Rumsfeld, 415 F.3d 33 (D.C. Cir. 2005).
} 
- Military commissions other than ordinary courts-martial of the sort authorized by the Uniform Code of Military Justice (UCMJ) are constitutionally permissible only if warranted by military exigency or Act of Congress.

- Given Hamdan's detention for years, far away from an active battlefield, no exigency warranted the use of military commissions in his case.

- No Act of Congress authorized the military commissions.

- Indeed, the UCMJ, by incorporating the international law of war, made the so-called Common Article 3 of the Geneva Conventions, governing treatment of prisoners and noncombatants, applicable to any effort to try combatants for war crimes.

- Common Article 3 applied notwithstanding the guerilla tactics of al Qaeda, because the conflict occurred in Afghanistan, a territory covered by the Conventions, making resort to the 1977 Protocols (to which the United States is not a signatory) unnecessary.

- Accordingly, detainees could only be tried before a tribunal that afforded the same protections as a court martial, absent impracticability.

- The commissions manifestly failed to afford the same procedural protections as courts martial.

- The administration had offered no persuasive evidence of the impracticability of using courts martial or their equivalent.

In portions of the lead opinion that Justice Kennedy did not join-because he thought them unnecessary to the resolution of the case-and that therefore represented the views of only four justices, Justice Stevens also made two further determinations:

- The indictment was invalid on the grounds that conspiracy, standing alone and without any charge of overt acts by the person charged during the wartime period, is not a recognized war crime.

- The military commissions were defective because they would have permitted important portions of the trial to occur outside the presence of the accused. (Although Justice Kennedy shared the majority's disapproval of other procedural differences between the military commissions and courts martial-especially the dependence of the former on persons within the chain of command-he did not reach the plurality's conclusion that they were defective for this further reason.)

\section{IMPLICATIONS}

We can identify at least six important implications of the foregoing determinations.

\section{Narrowing the World War II Precedents}

As discussed above in connection with the Hamdi and Rasul decisions, ever since the Bush administration decided that military detention and military com- 
missions would feature in its response to the attacks of 11 September 2001, the administration has invoked World War II-era cases as support for its approach. In both Quirin and Eisentrager, as well as a third case, In Re Yamashita, ${ }^{23}$ the Court had in one way or another rejected a challenge to the outcome of a military tribunal.

Critics of administration policies had urged the Supreme Court to repudiate its World War II-era jurisprudence and return to the principles announced in a Civil War-Era case, Ex Parte Milligan. ${ }^{24}$ In Milligan, the Court stated, in sweeping terms, that where no military emergency prevents the civilian courts from operating, military courts are unconstitutional.

Justice Stevens did not exactly oblige these critics in Hamdan, but he may have given them something better: Without overruling any of the World War II cases, he said that in important respects, they had been rendered inapplicable by changes in federal law and the international law of war. Further, he actually invoked these cases to bolster his arguments in light of those changes.

\section{Affirming the Role of Congress}

Hamdan was also a blow to the administration's broad assertion of presidential power. In presidential signing statements and other contexts, the Bush administration has repeatedly claimed that as Commander in Chief of the armed forces, the president has broad discretion to act in military matters.

That claim is partly right but mostly misleading. There is an important difference between, on the one hand, the president's power to act to defend the country where Congress has remained silent or authorized his action, and, on the other hand, the president's attempts to act in a manner contrary to congressional mandate. In the latter case, Supreme Court case law has repeatedly made clear, the president cannot act contrary to a valid enactment of Congress. ${ }^{25}$

In both the lead opinion of Justice Stevens and the concurring opinion of Justice Kennedy, the Hamdan Court reaffirmed this bedrock principle. The Constitution expressly grants to Congress numerous powers over the conduct of war and the armed forces. Accordingly, the Court ruled, the president's status as Commander in Chief gives him no authority to contravene the UCMJ or the international law of war that it incorporates.

Thus, Hamdan must be understood as having not all that much to do with individual rights, and everything to do with separation of powers. As both Justice Kennedy and Justice Breyer emphasized in their respective concurring opinions, if the President truly needed the powers he asserted in Hamdan,

\footnotetext{
${ }^{23}$ In Re Yamashita, 327 U.S. 1 (1946).

${ }^{24}$ Ex Parte Milligan, 71 U.S. 2 (1866).

${ }^{25}$ The leading precedent is Youngstown Co. v. Sawyer, 343 U.S. 579 (1952), commonly called "the Steel Seizure Case."
} 
Congress could give them to him. And indeed, Congress did just that a few months later when it enacted the MCA.

\section{The Applicability of the Geneva Conventions}

The Hamdan Court (including Justice Kennedy on this point) found the Geneva Conventions' requirement that enemy detainees be tried, if at all, by tribunals equivalent to civilian courts or regular courts martial applicable to alleged al Qaeda members. Although not directly relevant to the Hamdan case itself, that determination might have had grave collateral consequences for military and Central Intelligence Agency (CIA) personnel who have used extreme methods of interrogation on captives, were it not for the fact that the MCA, enacted several months after Hamdan, provides partial immunity to U.S. personnel for past breaches. The precise scope of that immunity remains uncertain, however, and so Hamdan retains importance on this point, insofar as it provides a window into the thinking of a majority of the Supreme Court.

Common Article 3 also requires that detainees "shall in all cases be treated humanely." This provision certainly bans torture and equally certainly bans some forms of interrogation-such as "waterboarding," which simulates the experience of drowning-that the administration is widely believed to have authorized under the assumption that the Geneva Conventions do not apply. As Justice Kennedy stated straightforwardly, yet potentially ominously for the administration: "By Act of Congress ... violations of Common Article 3 are considered 'war crimes,' punishable as federal offenses, when committed by or against United States nationals and military personnel," and "there should be no doubt ... that Common Article 3 is part of the law of war as that term is used in" the UCMJ. ${ }^{26}$

\section{Indefinite Detention Remains an Option}

In the wake of Hamdan, some human rights organizations and countries whose nationals were being held (and, as of this writing, continue to be held) at Guantanamo Bay seized upon the ruling as grounds for the administration to close the prison there, an option that even President Bush has on occasion stated he would like to pursue. ${ }^{27}$

Yet the Hamdan ruling in no way casts doubt on the ability of the government to detain alleged enemy combatants at Guantanamo. The majority conceded that persons who have fairly been determined to be enemy combatants can be held as long as hostilities last. Given the continuing conflict in Afghanistan, not to mention the broader "war on terror," that means the Guantanamo Bay prison can remain open for business.

\footnotetext{
${ }^{26}$ Hamdan, 126 S. Ct. at 2802 (Kennedy, J., concurring in part).

${ }^{27}$ See Linda Greenhouse, "The Ruling on Tribunals: The Overview; Justices, 5-3, Broadly Reject Bush Plan to Try Detainees," The New York Times, 30 June 2006.
} 
Thus, for civil libertarians Hamdan may seem worse than a pyrrhic victory. It says that the government cannot put detainees on trial because the military commissions as originally established were defective, but the ruling allows detainees to be held without trial indefinitely. Such a "victory" takes detainees out of the frying pan and throws them into the fire. Perhaps the most that can be said in this regard is that the Hamdan ruling adds to the moral authority of those who want to see the Guantanamo Bay prison closed.

\section{The Secret Prison Alternative}

Even before enactment of the MCA, the administration may have had at its disposal a ready means to circumvent the Hamdan ruling. It could simply have moved the Guantanamo Bay prisoners to another, perhaps secret, site. After all, the Rasul Court's determination that federal courts had jurisdiction over habeas corpus petitions filed by aliens held at Guantanamo Bay was based in part on the justices' refusal to apply the presumption that statutes lack extraterritorial effect: because the United States exercised sovereignty in all but name over Guantanamo Bay, they said, application of the habeas statute to petitions originating there did not count as extraterritorial.

Suppose, then, that the administration moved the Guantanamo Bay detainees to a prison in a friendly eastern European or central Asian country. Might the presumption against extraterritoriality then bar the filing of a habeas petition? The Rasul case leaves this possibility open.

Accordingly, and again, even without the congressional assistance it received in the MCA, the administration could find a way to try captives by military commission abroad in manifest violation of the Hamdan ruling, because the courts, having no jurisdiction, would be powerless to stop such trials. In fact, however, two events have made this option unlikely, at least in the short run. First, the passage of the MCA probably renders the use of other sites unnecessary. Second, rather than moving Guantanamo Bay detainees to other sites, in early September, the Bush administration announced that it was doing just the opposite, moving fourteen detainees from secret CIA prisons to Guantanamo Bay for trial by military commission. ${ }^{28}$

\section{The Precariousness of the Hamdan Majority}

The Hamdan case was decided by a 5-3 margin, but it is quite clear that if Chief Justice Roberts had not been recused, he would have voted with the dissenters. After all, he voted against Hamdan's claims as an appellate court judge. Thus, going forward, the case should be regarded as resting on a single vote.

\footnotetext{
${ }^{28}$ See Sheryl Gay Stolberg, "Threats and Responses: The Overview; President Moves 14 Held in Secret to Guantanamo," The New York Times, 7 September 2006.
} 
Justice Stevens, the author of Hamdan, is eighty-six, and though he appears to be in remarkably good shape, rumors of his imminent retirement inevitably circulate. To be sure, even if one of the justices in the Hamdan majority should retire in the near future, one or more of the dissenters might choose to leave the result in place out of respect for precedent, at least to the extent that the MCA does not supersede it. But on the broader question of how to understand the Constitution's allocation of power between the president and Congress, there is no reason to think that any of the Hamdan dissenters would soften his propresident view.

We may rightly regard Hamdan as a victory for the principle of checks and balances, even if, as an immediate practical matter, it will have little impact in light of the MCA. If the Supreme Court's point in Hamdan was that the president cannot establish military commissions without congressional approval, subsequent congressional approval does not show that the Court was wrong; it shows instead that Congress, finally, took some responsibility for the treatment of detainees.

Yet even conceived as a victory for the principle of checks and balances, Hamdan will not necessarily prove a lasting victory. Whether it does will depend very much on how seriously the Senate takes that very principle if and when it next confronts a Supreme Court nominee with a commitment to broad presidential power. 


\section{From the Editor:}

In this issue...

GARY C. JACOBSON analyzes the 2006 midterm election as a referendum on the performance of President Bush, the war in Iraq, and the Republican Congress. He argues that the Democrats won control of Congress by nationalizing the election and exploiting widespread public discontent with the Republican regime to overcome the Republicans' formidable structural advantage in present-day electoral politics.

DANIEL BYMAN challenges the view that proliferation and terrorism are similar problems and that the policies to combat them necessarily operate in harmony. Policymakers concerned about nuclear terrorism should focus on helping potential leakers improve security and on guarding against the rise of hostile ideological states.

MICHAEL C. DORF describes the interactions among the three branches of the federal government in addressing the detention and trial of captives in the war in Afghanistan and the broader "war on terror." He explains that the Supreme Court's repeated rejections of the Bush administration's sweeping assertions of wartime authority have erected few insurmountable obstacles to administration policy. Instead, the Court has required the administration to seek authority from Congress, which in turn has shown little appetite for reining in the President.

HUGH HECLO argues that both secular and religious political activists have found it advantageous to demonize each other by using the idea of America as a Christian nation. Citizens can gain a more mature understanding of the relationship between Christianity and American nationhood by considering different domains of variation in America's alleged Christian-ness.

JON A. SHIELDS unearths a surprising relationship between the Christian right and democratic ideals. Although Christian right leaders are strident in the context of mobilization, they also encourage their activists to embrace civility and public reason in the public square. This fact highlights a deeper tension between the democratic ideals of participation and deliberation.

DAVID A. REZVANI examines the controversy surrounding Puerto Rico's constitutional status and rejects both of the traditional views on this issue. Puerto Rico is neither an American colony nor are its powers legally safeguarded by its 1952 "compact" with the United States. Instead, mirroring the historic British dominions, unwritten constitutional rules defend Puerto Rico's constitutional status, making it into a partially sovereign polity known as a "federacy."

Demetrios James Caraley

Arthur M. Schlesinger, Jr. 1917-2007

The Academy of Political Science and Political Science Quarterly mourn the death of the eminent political and social historian Arthur M. Schlesinger, Jr. He was a faithful member of the Academy for over forty-five years and a hardworking member of the Quarterly's Editorial Board for over thirty years. The whole world of scholarship will miss him as we most certainly will.

-D.J.C. 